\title{
ELISA for Detection of Soya Proteins in Meat Products
}

\author{
Eva Renčová1, Bohuslava Tremlová ${ }^{2}$ \\ ${ }^{1}$ Veterinary Research Institute, Brno, Czech Republic \\ ${ }^{2}$ Department of Vegetable Food and Production, Faculty of Veterinary Hygiene and Ecology, \\ Veterinary and Pharmaceutical University Brno, Czech Republic
}

Received July 30, 2008

Accepted June 30, 2009

\begin{abstract}
Indirect competitive ELISA method for the detection of soya proteins in meat products was developed. The detection limit of the method is $0.5 \%$ of the weight of added soya protein. A total of 131 meat product samples such as salamis or sausages from the Czech Republic market were investigated for the presence of soya proteins. Soya proteins were detected in $84 \%$ of the investigated samples without any declaration on the package of the product. The use of vegetable additives, namely soya in meat products in the market of the Czech Republic is very frequent and the restriction of its usage by legislation relates only to some kinds of durable products and ham (Act 264/2003 Coll.). The need for sensitive inspecting methods for soya protein detection is not only associated with the economic aspect (adulteration), but mainly with consumer health protection in case of allergy to soya proteins.
\end{abstract}

Detection, immunochemical method, meat products, package declaration

Addition of vegetable components to meat products is nowadays a common practice, mainly for technological and economic reasons. Plant additives participate in water absorption, emulgating properties, and the ability to form fluffy structures, temperature stability and increased total content of proteins. Soya protein markedly increases waterbinding capacity, which has an adverse effect on the product durability. These characteristics have been known for a long time and are often applied in the production of meat products (Bookwalter 1978; Lusas and Riaz 1995). Vegetable proteins can also be used for the adulteration of meat products (Flores Mungula et al. 2000; Leitner et al. 2006).

The decision of the state supervision authorities whether the legislation requirements of qualitative indicators have been met is based mostly on laboratory testing. Hence, it is necessary to have a wide array of analytical methods available to ascertain adulteration or authenticity of particular food commodities, and to develop novel methods.

A number of methods exist for the detection of plant proteins in foodstuffs. Microscopic methods have been traditionally used for analysis of the materials of vegetable and animal origin and together with histochemical and immunohistochemical techniques for analysis of meat products or other ready-to-use foodstuffs (Flint 1994; Egelandsdal et al. 1991; Boutten et al. 1999; Tremlova et al. 2007). Immunochemical methods are often used under practical conditions (Macedo-Silva et al. 2000; Moriyama et al. 2005; Morishita et al. 2008; Pospiech et al. 2009) and the methods of molecular biology have been also developed (Meyer et al. 1996; Hernandez et al. 2006). Chromatography methods have been used for the detection of soya proteins, too (Castro Rubio et al. 2005; Criado et al. 2005). Moreover, novel homogenous immunoassay for soya protein determination in food samples using gold nanoparticles as labels and light scattering detection was presented (Sánchez-Martínez et al. 2009).

The purpose of the present study was to develop an indirect competitive ELISA method and to monitor the frequency of adding soya proteins to meat products and to check the consensus of the known or declared composition with the results of the analysis.

Address for correspondence:

MVDr. Eva Renčová, Ph.D.

Veterinary Research Institute

Department of Analytical Biotechnology

Hudcova 70, 62100 Brno, Czech Republic
Phone: +420533331617

Fax: +420541211229

E-mail: rencova@vri.cz

http://www.vfu.cz/acta-vet/actavet.htm 


\section{Materials and Methods}

Immunisation procedure and antibody preparation

For the first dose, the immunisation antigen of extracted proteins from soya isolate (Pragosoja, Czech Republic) according to Rittenburg et al. (1987) was mixed 1:1 with complete Freund's adjuvant (Sigma, USA) and administered intradermally in ten sites on the back of three-month-old New Zealand white rabbits $(0.4 \mathrm{mg}$ protein). Booster applications with Freund's incomplete adjuvant were made after 4 weeks, and then again after two weeks. After the last booster, the animals were bled by cardiac puncture. Sera were separated by centrifugation $\left(1000 \times g\right.$ at $\left.4{ }^{\circ} \mathrm{C} 20 \mathrm{~min}\right)$ and stored at $-20^{\circ} \mathrm{C}$. Specificity of the antibody was improved by saturation with the cross reacting antigens followed by centrifugation (Hayden 1979).

Characterisation of samples

The heat-processed meat product samples were subject to analysis. These were mostly various sausage and salami types randomly purchased in the market chain of the Czech Republic. A total of 131 meat product samples were examined for the presence of soya proteins.

\section{Sample processing}

Samples of $100 \mathrm{~g}$ of meat products were processed in a blender with $100 \mathrm{ml}$ of PBS, the homogenate was centrifuged at $10000 \times \mathrm{g}$ and $4{ }^{\circ} \mathrm{C}$ for $15 \mathrm{~min}$ and the supernatant was used for analysis.

ELISA method

The indirect competitive ELISA method was prepared according to Rencova et al. (2000) and then modified for the detection of soya proteins. ELISA was conducted utilizing $100 \mu \mathrm{l}$ well system with the application of solid-phase soya isolate antigen followed with the addition of sample extracts and the respective polyclonal New Zealand White rabbits anti soya isolate antibody of own provenance, peroxidase anti-rabbit conjugated antibody SwAR (Sigma-Aldridge, USA), and tetramethylbenzidine (TMB) substrate (Sigma-Aldridge, USA) and measurement of final absorbance at $450 \mathrm{~nm}$. Detection limit of the semi-quantitative ELISA method was $0.5 \%$ of the weight of added plant protein (Fig. 1) (VúVeL, v.v.i. No 32/2007).

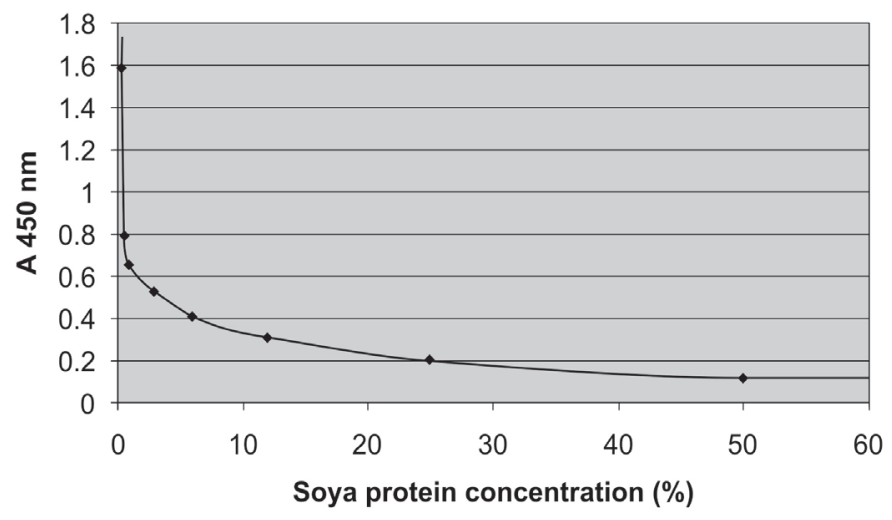

Fig.1. Standard curve for soya protein

\section{Results and Discussion}

The indirect competitive ELISA method developed in our study showed to be sensitive and specific enough to detect meat product adulteration. It can detect added soya protein in the amount of less than $0.5 \%$ mass fraction of the plant protein added, regardless of whether the added soya was textured, isolated or concentrated. The detection limit of the method is sufficient, although more sensitive ELISA methods exist that can detect $0.07 \%$ (Castro Rubio et al. 2005) or even $0.4 \mu \mathrm{g}(0.4 \mathrm{ppm})$ per $1 \mathrm{~g}$ (Koppelman et al. 2004). In addition, the quantitative detection base on the conglycinin detection has been described (Moryiama et al. 2005). Soya proteins belong to major food allergens (Directive 2003/89/EC). Thus, the sensitivity of the methods is mainly important for detections of threshold concentrations of allergens. The method is specific enough to detect soya proteins only. From the specificity 
testing weak cross-reactivity is seen to other leguminous plants as beans, lentil and peas. Cross-reactivity has been eliminated using saturation (immunoabsorption) of antibody with the respective cross-reacting antigens, followed by centrifugation (Hayden 1979). Cross reactivity did not occur when testing other additives commonly used in meat product recipes such as casein, ovalbumin or wheat flour.

A total of 131 samples of different kinds of heat-treated meat products, largely of sausage and soft salami types were analysed. Among these 131 investigated samples, the soya protein was detected with certainty in $110(84 \%)$ samples, the results were dubious in 5 cases $(3.9 \%)$ and soya protein was not detected in $16(12.1 \%)$ cases (data not shown).

In 49 products with declared composition by the manufacturer examined for soya protein were only general data (plant protein) in $16(32.7 \%)$ cases. Soya was declared in $21(42.9 \%)$ cases, no plant protein was declared in $12(24.5 \%)$ samples. Plant protein declared generally on the products was confirmed by the ELISA method in all 16 samples. Declared soya was confirmed in $17(82.2 \%)$ of 21 samples. In spite of no plant protein declaration the presence of soya was detected in $10(72 \%)$ of 12 products. Two products were in agreement with the declared composition. The declared presence of soya protein was not confirmed in four cases (Table 1).

The group of investigated samples included packaged products or products packaged on the consumer's request. According to the legislation (Directive 2003/89/EC, Act 120/2008 Coll., Regulation No. 101/2007 Coll.), the presence of potential allergen must be declared on the consumers' packages, either on the foodstuff cover or on the exterior of the packing or its parts. In case of unpackaged foodstuffs or if it is not possible to declare the date on the exterior cover of the packing, it must be a part of documentation that accompanies the foodstuff in the shop. However, it does not follow from the legislation how the consumer should be informed if a foodstuff is packaged in the shop.

Our results showed that the declared soya proteins were not in agreement with the detected results, i.e. soya protein was detected in $84 \%$ samples without any declaration (neither general) on the product.

In conclusion, our study shows that the use of vegetable additives, namely soya in meat products in the market of the Czech Republic is very frequent and the restriction of its usage by legislation relates only to the use of plant protein in some kinds of durable products and ham (Act 264/2003 Coll.). The need for sensitive methods for plant protein detection is not only associated with the economic aspect (adulteration), but also another important aspect: the protection of consumers' health threatened by allergy to plant protein. Consumers often encounter potential allergenic components namely in the cases of meat products packaged in the shops without being informed despite valid legislation (Directive 2003/89/EC).

\section{ELISA metoda pro detekci sójových proteinů v masných výrobcích}

Byla vyvinuta nepř́má kompetitivní ELISA metoda pro detekci sójových proteinů. Detekční limit metody je $0.5 \%$ hmotnostního přídavku sójového proteinu. Celkem 131 vzorků masných výrobků salámů a párků z české tržní sítě bylo vyšetřeno na přítomnost sójových proteinů. Sója byla detekována v 84\% výrobků bez jakékoliv deklarace na obalu výrobku. Používání rostlinných proteinů zejména sóji do masných výrobků v České republice je velmi časté a omezení jejího používání legislativou je dané jen u některých trvanlivých masných výrobků a šunky (Vyhláška 264/2003 Sb.). Potřeba citlivých kontrolních metod pro detekci sójových proteinů není důležitá pouze $\mathrm{z}$ důvodů ekonomických (falšování), ale především z důvodu ochrany zdraví spotřebitele v případě alergie na sójové proteiny. 
Table 1. Results obtained by the examination of meat products with declared composition

\begin{tabular}{|c|c|c|c|c|}
\hline \multirow[b]{2}{*}{ Sample No. } & \multirow[b]{2}{*}{ Sample name } & \multicolumn{2}{|c|}{ Declared } & \multirow[b]{2}{*}{ ELISA } \\
\hline & & $\begin{array}{c}\text { Generally } \\
\text { (plant proteins) }\end{array}$ & $\begin{array}{c}\text { Specifically } \\
\text { - soy }\end{array}$ & \\
\hline 3 & Liver sausage & & + & - \\
\hline 10 & Soft salami & & + & - \\
\hline 13 & Bratislava salami & & + & + \\
\hline 15 & Chicken salami & & + & + \\
\hline 16 & Cheap salami & & + & + \\
\hline 17 & Minisalami & & + & + \\
\hline 18 & Cheap sausage & & + & - \\
\hline 19 & Chicken sausage & + & & + \\
\hline 20 & Delicious sausage & + & & + \\
\hline 21 & Bratislava salami & & + & - \\
\hline 22 & Knackers & & + & + \\
\hline 24 & Turkey delicious sausage & + & & + \\
\hline 25 & Knackers & + & & + \\
\hline 26 & Spa salami & + & & + \\
\hline 27 & Slovak salami & + & 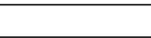 & + \\
\hline 28 & Chicken coctail sausage & & + & + \\
\hline 29 & Hungarian sausage & + & & + \\
\hline 30 & Sausage & & + & + \\
\hline 32 & Bratislava sausage & & & + \\
\hline 33 & Klaus sausage & & + & + \\
\hline 34 & Strip sausage & & + & + \\
\hline 35 & Soft sausage & & + & + \\
\hline 37 & Chicken salami & & + & + \\
\hline 45 & Cheese sausage & + & & + \\
\hline 46 & Knackers & + & & + \\
\hline 47 & Bangers & + & & + \\
\hline 48 & Wieners & + & & + \\
\hline 49 & Sausage & & + & + \\
\hline 50 & Delicious sausage & + & & + \\
\hline 52 & Cheap salami & & & + \\
\hline 53 & Sausage Extra & & & + \\
\hline 54 & Cheese sausage & & & - \\
\hline 55 & Chicken sausage & + & & + \\
\hline 56 & Spis sausage & & & + \\
\hline 57 & Tramp sausage & & & + \\
\hline 59 & Bratislava salami & & + & + \\
\hline 60 & Ham sausage & & & - \\
\hline 61 & Czech Knackers & & & + \\
\hline 62 & Knackers & + & & + \\
\hline 63 & Turkey hot-dog & + & & + \\
\hline 64 & Eso sausage & & & + \\
\hline 65 & Strip sausage & & & + \\
\hline 101 & Minisalami & & + & + \\
\hline 107 & Bavaria chopped meat & & + & + \\
\hline 115 & Gladiator & & + & + \\
\hline 116 & Knackers & + & & + \\
\hline 120 & Franks & & & + \\
\hline 121 & Mushroom delicious sausage & & + & + \\
\hline 123 & Highlander & & & + \\
\hline
\end{tabular}




\section{Acknowledgements}

This work was supported by the Ministry of Agriculture of the Czech Republic (Grants MZe 0002716201 and 1B53004 and Veterinary Scientific Committee).

\section{References}

Anonymous: Directive 2003/89/EC amending Directive 2000/13/EC as regards indication of the ingredients present in foodstuffs. OJL 308, 25. 11. 2003, pp. 15-18

Anonymous: Decree of Ministry of Agriculture amending Decree No. 264/2003 Coll. implementing § 18 letter a), d), g), h), i) and j) of Act No. 110/1997 Coll. on foodstuffs and tobacco products and amendment and supplement to some connected Acts, in the wording of later regulations, for meat, meat products, fish, other water animals and products thereof, eggs and eggs products. Collection of Acts, pp. 4348-4370

Anonymous: Regulation of Ministry of Agriculture No. 101/2007 Coll. on methods for labelling of foodstuffs and tobacco products. Collection of Acts, pp. 1163-1176

Anonymous: Law No. 120/2008, Coll. on food and tobacco products and on the amendment of related Laws. Collection of Acts, 2008, pp. 1510-1527 (later Act Amendments)

Boutten B, Humbert C, Chelbi M, Durand P, Peyraud D 1999: Quantification of soy proteins by association of immunohistochemistry and video image analysis. Food Agric Immunol 11: 51-59

Bookwalter GN 1978: Soy protein utilization in food systems. Adv Exp Med Biol 105: 749-766

Castro-Rubio F, Garcia MC, Rodriguez R, Marina ML 2005: Simple and inexpensive method for the reliable determination of additions of soybean proteins in heat-processed meat products: An Alternative to the AOAC Official Method. J Agric Food Chem 53: 220-226

Criado M, Castro-Rubio F, Garcia-Ruiz C, Garcia MC, Marina ML 2005: Detection and quantitation of additions of soybean proteins in cured-meat products by perfusion reversed-phase high-performance liquid chromatography. J Sep Sci 28: 987-995

Egelandsdal B, Kidman S, Hermansson AMM 1991: Immunohistochemical techniques applied to raw and mildly heat treated meat systems. Food Structure 10: 303-316

Flint FO 1994: Food microscopy. Microscopy Handbooks 30. Bios Scientific Publishers Limited, Oxford, 125 p.

Flores-Mungula ME, Bermudez-Almada M. C., Vazquez-Moreno LA 2000: Research Note: Detection of adulteration in processed traditional meat products. J Muscle Foods 11: 319- 325

Hernandez M, Esteve T, Pla M 2006: Real-time polymerase chain reaction based assays for quantitative detection of barley, rice, sunflower, and wheat. J Agric Food Chem 53: 7003-7009

Koppelman SJ, Lakemond CMM, Vlooswijk R, Hefle SL 2004: Detection of soy protein in processed foods: Literature Overview and New Experimental Work. J AOAC Int 87: 1398-1407

Leitner A, Castro-Rubio F, Marina ML, Lindner W 2006: Identification of marker proteins for the adulteration of meat products with soybean proteins by multidimensional liquid chromatography-tandem mass spectrometry. J Proteome Res 6: 2424-2030

Lusas EW, Riaz MN 1995: Soy protein products processing and use. J Nutr 125: 573S-580S

Macedo-Silva A, Barbosa SFC, Alkmin MGA, Vaz AJ, Shimokomaki M, Tenuta, AA 2000: Hamburger meat identification by Dot-ELISA. Meat Sci 56: 189-192

Martin R, Azcona JI, Tormo J, Hernandez DE 1992: Immunoadsorption chromatography. Partial purification of pig-specific muscle soluble proteins. Fleischwirtschaft 72: 916-917

Meyer R., Chardonness F, Hubner P, Luthy J 1996: Polymerase Chain Reaction (PCR) in the quality and safety assurance of food: Detection of soya in processed meat products. Z Lebensm Unters-Forsch 203: 339-344

Morishita N, Kamiyja K, Matsumoto T, Sakai S, Teshima R, Urisu A, Moriyama T, Ogawa T, Akiyama H, Morimatsu F. 2008: Reliable enzyme-linked immunosorbent assay for the determination of soybean proteins in processed foods. J Agric Food Chem 56: 6818-6824

Moriyama T, Machidori M, Ozasa S, Maebuchi M, Urade R, Takahashi K, Ogawa T, Maruyama N 2005: A novel enzyme-linked immunosorbent assay for quantification of soybean beta conglycinin, a major soybean storage protein, in soybean and soybean food products. J Nutr Sci Vitaminol 51: 34-39

Pospiech M, Tremlova B, Rencova E, Randulova Z 2009: Immunochemical detection of soya protein optimisation and verification of the method. Czech J Food Sci 27: 11-19

Rencova E, Svoboda I, Necidova L 2000: Identification by ELISA of poultry, horse, kangaroo, and rat muscle specific proteins in heat-processed products. Vet Med-Czech 45: 353-356

Sánchez-Martínez ML, Aquilar-Caballos MP, Gómez-Hens A. 2009:Homogeneous immunoassay for soy protein determination in food samples using gold nanoparticles as labels and light scattering detection. Anal Chim Acta 16: 58-62

Tremlova B, Pospiech M, Hubalkova Z, Starha P, Malcova V, Rencova E 2006: Quantitative histological analysis of model samples. Arch Lebensmittelhyg 58: 19-22

Rittenburg JH, Adams A, Palmer, J, Allen, JC 1987: Improved Enzyme-linked immunosorbent assay for determination of soy protein in meat products. J AOAC Int 70: 582-587 
